\title{
Internal Resources Mobilization and Financial Control of Government Budget in Southwest Nigeria
}

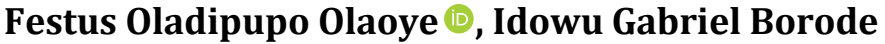 \\ Department of Accounting, Ekiti State University, Ado Ekiti, Nigeria \\ Email: oladipupo.olaoye@eksu.edu.ng
}

How to cite this paper: Olaoye, F.O. and Borode, I.G. (2019) Internal Resources Mobilization and Financial Control of Government Budget in Southwest Nigeria. Journal of Service Science and Management, 12, 531-541.

https://doi.org/10.4236/jssm.2019.124036

Received: April 1, 2019

Accepted: June 22, 2019

Published: June 25, 2019

Copyright $\odot 2019$ by author(s) and Scientific Research Publishing Inc. This work is licensed under the Creative Commons Attribution International License (CC BY 4.0)

http://creativecommons.org/licenses/by/4.0/

\section{(c) (i) Open Access}

\begin{abstract}
This study examined the impact of internal resources mobilization and financial control of government budget in southwest Nigeria. The study focused on all the southwest states over a period of 15 years (2003 to 2017). Pooled OLS estimation, fixed effect estimation and random effect estimation were used in the study, alongside trend analysis. Result showed significant trend of resources mobilization performance, though with varying strength of fluctuation across the sampled states. Internally generated revenue exert positive significant impact on government financial control measured in terms of revenue budgeted actual variance $(0.407566, \mathrm{p}=0.000<0.05)$ and in terms of expenditure budgeted actual variance $(0.1694784, \mathrm{p}=0.000<0.05)$. This study concluded that internal resources mobilization has significant positive influence on the level of financial control of government budget in Southwest Nigeria. Hence state government in southwest Nigeria should ensure adequate generation of revenue within the States, so as to boost the level of financial control in government budget process.
\end{abstract}

\section{Keywords}

Internal Resources Mobilization, Financial Control, Government Budget, Southwest Nigeria

\section{Introduction}

Government budget in Nigeria has what could be termed a chequered history and is as old as the colonial rule in Nigeria [1] [2]. [3] affirmed that government budgeting in Nigeria has passed through different stages from the period before 1977, Ministry of Finance Committee to the Onosode Committee of 1984, Phil- 
lips Committee of the year 2000 and to the provision of the Fiscal Responsibilities Act, 2007. The Nigerian budgeting system was inherited from British colonial administration. Since independence, the Nigerian budgeting experience has been under both the military and the civilian regimes. Under the military, the exact stages of budgeting procedures may not be really defined. The legislative consideration stage is completely absent, as there was no separate legislative arm of government. As military regimes run unitary governments and operate unified fiscal system, the budgetary process is fairly straight forward and less cumbersome [3] [4] [5]. After fifteen years (1983-1998) of military rule, the Nigerian budgeting system came under the democratic government in May, 1999. The democratic system offers a more complex environment within which decision about the objectives and resource for implementing them take place. The allocation of the public resources is influenced by the interaction of the governmental machinery and the influence of various stakeholders and interest groups that are affected by public expenditure [6]. The democratic framework has respect for transparency and accountability in public resource management [3].

[7] argued that budgeting, though fraught with a lot of weaknesses such as being an annual performance ritual to managers, yet there is no other managerial process that translates qualitative mission statements and corporate strategies into action plans, links the short-term with the long term, and brings together managers from different hierarchical levels and from different areas than budgeting. [7] further submitted that what organisation should embark on is a paradigm shift from "one-dimensional financial models" towards "integrated frameworks" to measure performance. Efforts have been going on the world over to reinforce and reform government budget as a potent tool for performance evaluation and financial control [8].

It is not only in Nigeria that budgeting is facing managerial and acceptability problems but around the world [9] [10] [11]. Budget has been tagged negatively with appellations such as "budgeting is a joke everyone knows it" [12]. [13] declared budgeting bankrupt and recommend that it should be "abolished". [14] said budget has caused more "damage than benefit". [15] said through budget people are taught to lie. The persecutions on budget as an inadequate tool of financial control and performance evaluation can be conveniently grouped into two schools of thought namely: "the beyond budgeting" and the "budgeting for reform". This position also tallies with the opinions of [16]. In the views of [17], the corporate world has made paradigm shift from total and absolute reliance on budget as the sole tool of setting performance metrics, control finance and measuring performance. Some of the inherent weaknesses in the Nigerian budget system militating against its implementation and financial control is the problem of over-dependence on oil revenues which is subject to price and demand vagaries in the world market. Oil revenue accounts for $75 \%$ for the consolidated revenues available for distributions to the three-tiers of government in Nigeria [18] [19] [20]. On the average oil revenue accounted $81.4 \%$. The implication of this that budget performance at the Federal, States and Local Governments level re- 
lies on oil revenue to the tune of more than $80 \%$. This is highly inimical to budget implementation and financial control in the public sector [18]. The justification for the area of study stems from the fact that most of the existing studies have looked into budget implementation for Nigeria as a whole, little is being heard and read about budget performances at the geopolitical zone. The six states were covered in order to give a full fledged view of the entire geopolitical zone. What is the trend of government performance in resources mobilization in Southwest States of Nigeria and that What is the impact of internal resources mobilization on financial control of government budget in Southwest States of Nigeria? Hence this study specifically analysed: trend of government performance in resources mobilization in Southwest States of Nigeria; and the impact of internal resources mobilization on financial control of government budget in Southwest States of Nigeria.

\section{Literature Review}

\subsection{Internal Revenue Mobilization}

Revenue is a general term for all monetary receipts accruing from both tax and non-tax sources as well as fees, grants and contributions constitute the live wire of the local government. Many developed and developing economies have focused on decentralization of the operations of the government with the sole objective of ensuring efficiency and effectiveness of the administration of state owned resources [21]. The strengthening of domestic revenue bases is essential to creating fiscal space for local developmental needs and eventually translates into the development of the public. This means that decentralization Revenue collection remains a prerequisite for the implementation of local government plans and programmes. [5] viewed tax as a system of imposing compulsory levy on all income, goods, services and properties of individuals, partnership, trustees, executors and companies by the government. Tax itself is an amount of money that you must pay to the government according to your income, property, goods that is used to pay for public services and perform other social responsibilities, while non-tax is the revenue accruing to the government other than tax and which is supported by law of the Federation. The history of man has shown that man has to pay tax in one form or the other that is either in cash or in kind, initially to his chieftain and later on a form of organized government [22]. Based on the above clarification, no system or rules can be effective whether foreign or native unless it enjoys some measures of financial independence.

\subsection{Financial Control}

Financial control is defined as being assisted by the provision of financial information to management by the accountant and the use of such techniques as budgetary control and standard costing, which highlight and analyses any variances [23]. Financial control is seen as a tool of management which provides information to monitor performances as dictated in the financial plan. It also 
uses budgetary control and standard costing as tools. As earlier mentioned that financial control is an instrument of financial management and a component of financial planning, a glimpse of the financial planning process as given by [24] confirms and posited that financial planning process involves the following facets: evaluating the current financial condition of the firm; analyzing the future growth prospects and options; appraising the investment options to achieve the stated growth objectives; projecting the future growth and profitability; estimating funds requirement and considering alternative finance options; comparing and choosing from alternative growth plans and financing options and measuring actual performance with planned performance. The three finance terminologies are closely related but differ in meaning. An early alignment of the trio is necessary for the purpose of their usage in businesses. Financial management is the broadest of the three terms and encompasses financial planning and control. [2] aptly described financial management as being concerned not only with the acquisition but with the application, conservation, timing, volume, and composition of funds in order to ensure an effective utilization of available resources.

[25] prescribed five basic characteristics of a financial plan using the acronym "SMART" standing for specific, measurable, achievable, realistic and timeliness. For example, it could be a financial management strategy for a firm to desire to increase profitability on a consistent percent per annum. That becomes an objective in respect of profitability. Financial planning will state in specific terms; what percentage increase per annum? That estimate becomes a goal or target under the plan. Financial planning goes ahead to identify what steps or policies can be pursued to bring about the desired increase in profitability? Such policies will include the following: aggressive marketing through sales promotion and increased depots, possible price increase, if the price elasticity of demand is inelastic, possible price decrease if the price elasticity for the product is elastic, manufacturing new product(s) for the existing market and manufacturing new product for new market. These are few of the options that can be pursued to achieve that purpose or target. Each of the options will be evaluated so as to adopt the best option. The adopted policy/(ies) will be embarked upon and continuously reviewed for assessment.

\subsection{Empirical Review}

[21] wrote on budget institutions and fiscal performance in Africa. He examined the relationship between budget institutions and fiscal performance in 46 African countries, made up of 45 countries of AU members and Morocco. The paper analyzed African budgetary system in isolation given that the regions comparatively high vulnerability to external shocks, large extent of external influence, underdeveloped financial markets, and weak state structures and political systems render the fiscal position of African countries generally more fragile than that of other developing countries. The objectives of this paper were to propose an index which allows for the assessment of the adequacy of budget institution 
in the specific context of African countries and analysed their impact on fiscal outcomes.

[26] also examined budget practices and procedures in Africa. He examined the budget practices and procedures of about twenty-five African countries, including Nigeria. Timeliness in the formulation, approval, execution and audit and evaluation was examined. The role of the executive and the legislatures, fiscal transparency, off-budget spending and Aid management were also examined. He linked the survey results to administrative traditions, reform efforts and political and economic realities. He mentioned areas of transparency and off-budget spending, budget execution and audit procedures and Aid management as areas that need attention.

[4] also examined the budget process and budgeting experience in Nigeria. Specific issues such as objectives and significance of government budget, the budget process, features of past budgeting experience including the issue of operation and maintenance expenditure, budgets in relation to fiscal disciplines and macroeconomic stability, and international experiences of fiscal frameworks for fiscal prudence were thoroughly examined. He pointed out the basic objectives of government budget as to relate expenditure decisions to specific policy objectives, and to existing and future resources; relate all major decisions to the state of the national economy; ensure efficiency and effectiveness in the implementation of public sector programmes and facilitate legislative control over the various phases of the budgeting process [27]. He however attributed high level of poverty, low economic performance in terms of economic growth and development as well as improved living standards of the citizenry to poor fiscal management, corruption, poor policies, indiscipline of the political leadership, non-observance of budgeting targets, absence of multi-year budgeting, lack of transparency and accountability, weaknesses in the institutional framework, and insufficient link of the budget with the national development plan, lapses in budget formulation arising from deficient techniques, poor budget implementations among others.

\section{Research Method}

\subsection{Model Specification}

This study modified the model used by [28] to investigate the role of statutory allocation in Nigerian states. The adapted model specified state's performance measured in terms of gross domestic product as a function of statutory allocation using internally generated revenue as a control variable as presented in Equation (1)

$$
Y_{i t}=\alpha_{0}+\alpha_{1} \mathrm{STA}_{i t}+\alpha_{2} \mathrm{IGR}_{i t}+\mu_{i t}
$$

This study replaced state performance with state financial control measured in terms of expenditure budgeted-actual variance and revenue budgeted-actual variance while internally generated revenue is used as the main variable. Hence the model for this study is specified in functional and linear forms to reflect the rela- 
tionship between Resources Mobilization within the states and Financial Control

$$
\begin{gathered}
\mathrm{RBAV}=\mathrm{f}(\mathrm{IGR}) \\
\mathrm{EBAV}=\mathrm{f}(\mathrm{IGR}) \\
\mathrm{RBAV}_{i t}=\alpha_{0}+\alpha_{1} \mathrm{IGR}_{i t}+\mu_{i t} \\
\mathrm{EBAV}_{i t}=\alpha_{0}+\alpha_{1} \mathrm{IGR}_{i t}+\mu_{i t}
\end{gathered}
$$

where IGR = Internally Generated Revenue, EBAV = Expenditure Budgeted-Actual Variance, $\mathrm{RBAV}=$ Revenue Budgeted-Actual Variance, $\mathrm{U}=$ stochastic error time.

\subsection{Scope and Source of Data}

The study examined the budget performances in the affected States for a period of fifteen fiscal years for each state from 2003 to 2017 making a total of ninety effective fiscal/budget years. Data on the budgeted and actual expenditure and revenue for each of the states sampled in the study were collected from budget and planning office of each states as contained in their annual budget, while data for internally generated revenue (IGR) were collected from both state's annual budget and national bureau of statistics for each of the years considered in the study.

\subsection{Method of Analysis}

This study made use of static panel estimation techniques such as pooled OLS estimator, fixed effect estimator and random effect generalized least square estimator. The static estimators were evaluated using post estimation test such as restricted F-test (to compare pooled OLS estimation result with the fixed effect estimation result for heterogeneity effect validation across sampled state, and over the period covered in the study) and Hausman test (to compare fixed effect estimation result with random effect estimation result in the quest to ascertain the most consistent and efficient estimation result).

\section{Data Analysis and Result}

\subsection{Trend Analysis}

This section presents the trend of government performance in resources mobilization in Southwest States, using the ratio of internally generated revenue to total revenue as a measure of government performance in resources mobilization. The trend of resources mobilization in the six state of the Southwest geopolitical zone is presented in Figure 1: using a line graph.

The trend of resources mobilization in Southwest States (as measured by the ratio of internally generated revenue to total revenue) presented in Figure 1 revealed that Lagos state top the league of resources mobilization in Southwest State Nigeria for the period understudied. In the year 2003 about 39 percent of the total revenue in Lagos State was generated internally, although fell in 2004 and 2005, the ratio still maintained an average figure of about 37.5 percent before a sharp increase to about 53 percent in 2003 which was on the average of 48 


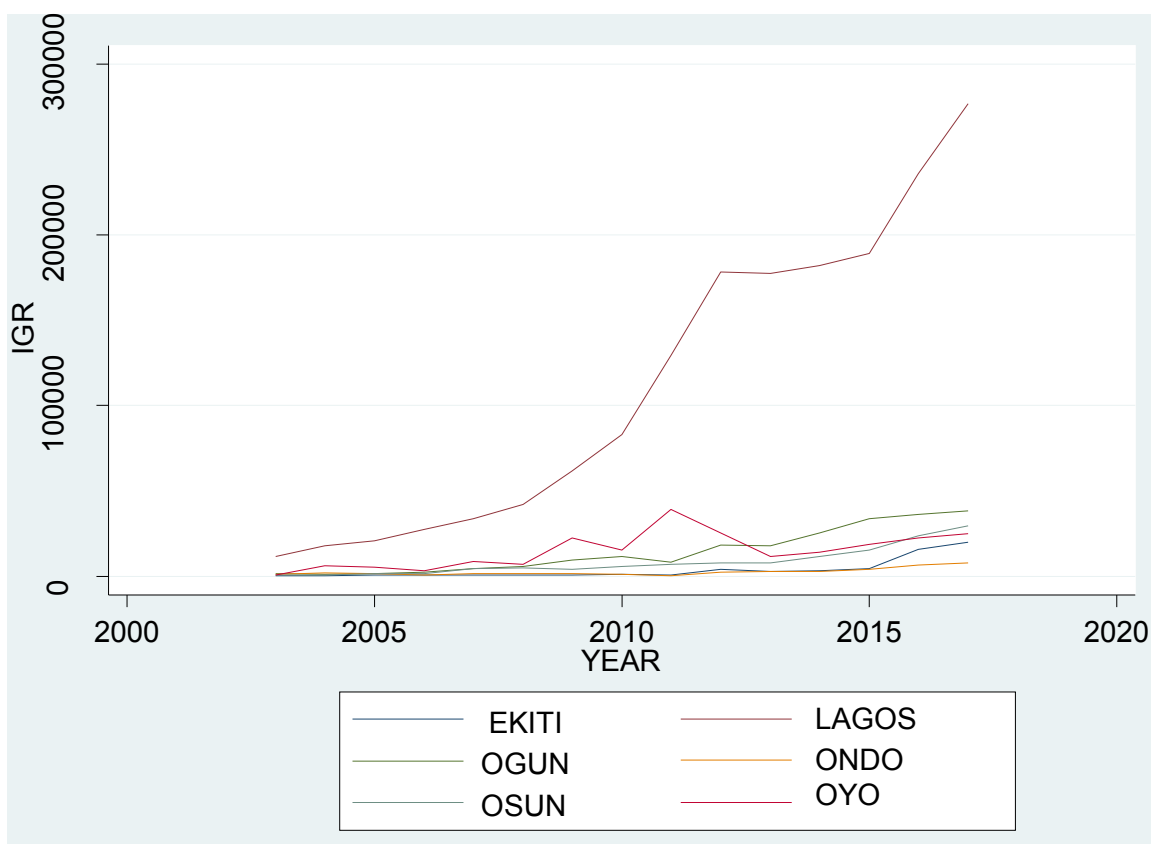

Figure 1. Trend of resources mobilization in southwest states. Source: Author's compilation (2019).

percent sustained between 2003 to 2014. Notably however resources mobilization in Lagos State maintained a leading trend for the period understudied, although in a fluctuating manner. The observed trend of resources mobilization in Lagos state, could be traceable to some fundamental attributes of the state which could include presence of ports, the state being the economic nerve of Nigeria with over 2000 industries, some strategic initiatives of the state's board of internal revenue to make tax assessment and payment convenient (e.g. establishment of mini tax offices and the introduction of self-filing system for individuals), the first of its kind in Nigeria, among others.

Close observation of Figure 1 also reveals that the next in line in resources mobilization in Southwest States is Oyo, the trend shows a sharp fluctuation pattern throughout the period covered, starting from 0.08 in year 2003 to 0.30 in the next period followed by a mild fall and rise in 2005 through 2008, before another sharp increase from 0.14 to 0.44 in 2009 , in which the trend-pattern continued to fluctuate in like manner for subsequent periods. Ogun State resources mobilization trend pattern shows a relatively mild fluctuation as it started increasing from 2003 through 2006 after which it shows a sharp increase which was considerably maintained throughout the period covered in a moderately fluctuating manner. Next in line is Osun state resources mobilization trend pattern which is almost akin to that of the Ogun state, only that the sharp increase came twice before a definite trend fluctuation pattern was established. Both Ondo and Ekiti States experienced a relatively falling trend of resources mobilization for the periods understudied, causing continuous fall from year 2003 through 2011 for the two States after which a mild rise ensued. 


\subsection{Analysis of the Impact of Internally Generated Revenue on Expenditure Budgeted-Actual Variance}

Pooled OLS estimates corresponding to the model specified to analyze the impact of internal resources mobilization on government budget financial control as measured in terms of expenditure budgeted-actual variance. The result reveals that internally generated revenue positively and significantly influences government budget financial control in Southwest States of Nigeria, with coefficient estimate of $0.1656504(p=0.050)$, fixed effect estimation result revealed that when heterogeneity effect across the states understudied was incorporated into the model as intercept term the impact of internally generated revenue on financial control measured in terms of expenditure budgeted actual variance remain positive and significant $0.2831304(\mathrm{p}=0.022<0.05)$. Random effect estimation result showed that when heterogeneity effect is incorporated into the model as component of error term, impact of internally generated revenue on expenditure budgeted actual variance is also positive and significant, with reported coefficient estimates of $.1694784(\mathrm{p}=0.045<0.05)$. Restricted F-test validated the existence of cross sectional uniqueness amidst sampled states with reported statistics of 12.30 ( $\mathrm{p}=0.0024<0.05)$, thus invalidating the restriction of the pooled OLS. Hausman test result of $1.02(\mathrm{p}=0.2280<0.05)$ also reflect that there is no significantly difference between the fixed effect and random effect estimates, therefore random effect estimation result presented in Table 1 is most consistent and efficient for analysing the impact of internally generated revenue on financial control measured in terms of expenditure budgeted-actual variance.

Pooled OLS estimates corresponding to the model specified to analyze the impact of internal resources mobilization on government budget financial control as measured in terms of revenue budgeted-actual variance. The result reveals that internally generated revenue positively and significantly influences government budget financial control in Southwest States of Nigeria, with coefficient estimate of $0.3966988(\mathrm{p}=0.000<0.05)$ Fixed effect estimation result revealed that when heterogeneity effect across the states understudied was incorporated into the model as intercept term the impact of internally generated revenue on financial control measured in terms of revenue budgeted actual variance remain positive and significant $0.5896748(\mathrm{p}=0.000<0.05)$. Random effect estimation result showed that when heterogeneity effect is incorporated into the model as component of error term, impact of internally generated revenue on revenue budgeted actual variance is also positive and significant, with reported coefficient estimates of $0.407566(\mathrm{p}=0.000<0.05)$. Restricted F-test validated the existence of cross sectional uniqueness amidst sampled states with reported statistics of $11.21(\mathrm{p}=0.0011<0.05)$, thus invalidating the restriction of the pooled OLS. Hausman test result of $1.72(\mathrm{p}=0.1892<0.05)$ also reflect that there is no significantly difference between the fixed effect and random effect estimates, therefore random effect estimation result presented in Table 2 is most consistent and efficient for analysing the impact of internally generated revenue on financial control measured in terms of revenue budgeted-actual variance. 
Table 1. Estimation result (Model 1). SERIES: EBAV IGR.

\begin{tabular}{|c|c|c|c|c|c|c|}
\hline Coefficient & Pooled & Prob & Fixed & Prob & Random & Prob \\
\hline $\mathrm{C}$ & 36049.42 & 0.000 & 22229.98 & $0.041^{\star}$ & 35949.93 & $0.000^{*}$ \\
\hline \multirow[t]{7}{*}{ IGR } & 0.1656504 & 0.050 & 0.2831304 & $0.022^{*}$ & 0.1694784 & $0.045^{*}$ \\
\hline & \multicolumn{2}{|c|}{$\mathrm{R}$-square $=0.2030$} & \multicolumn{2}{|c|}{ R-square $=0.7081$} & \multicolumn{2}{|c|}{ R-square $=0.6430$} \\
\hline & \multicolumn{2}{|c|}{ Adj R-square $=0.1821$} & \multicolumn{2}{|c|}{ Adj R-square $=0.6736$} & \multicolumn{2}{|c|}{ Wald $\operatorname{chi} 2(5)=4.01$} \\
\hline & \multicolumn{2}{|c|}{ F-statistics $=3.95$} & \multicolumn{2}{|c|}{ F-statistics $=11.68$} & \multicolumn{2}{|c|}{ Prob $>$ chi $2=0.0453$} \\
\hline & \multicolumn{2}{|c|}{$\operatorname{Prob}(F-$ stat $)=0.0499$} & \multicolumn{2}{|c|}{$\operatorname{Prob}(\mathrm{F}-\mathrm{stat})=0.0000$} & & \\
\hline & \multicolumn{6}{|c|}{ Restricted F-test $=12.30(\mathrm{p}=0.0024<0.05)$} \\
\hline & & & \multicolumn{4}{|c|}{ Hauman Test $=1.02(\mathrm{P}=0.2280<0.05)$} \\
\hline
\end{tabular}

Source: Author's computation, (2019).

Table 2. Estimation result (Model 2). SERIES: RBAV IGR.

\begin{tabular}{ccccccc}
\hline Coefficient & Pooled & Prob & Fixed & Prob & Random & Prob \\
\hline C & 28064 & 0.000 & 20144.88 & $0.025^{*}$ & 27781.56 & $0.000^{*}$ \\
IGR & 0.3966988 & 0.000 & 0.5896748 & $0.000^{*}$ & 0.407566 & $0.000^{*}$ \\
& R-square $=0.2621$ & R-square $=0.6518$ & R-square $=0.7621$ \\
Adj R-square $=0.2537$ & Adj R-square $=0.6049$ & Wald chi2 $(5)=31.30$ \\
F-statistics $=31.25$ & F-statistics $=7.51$ & Prob $>$ chi2 $=0.0000$ \\
Prob(F-stat $)$ & $=0.0000$ & Prob (F-stat $)=0.0000$ & & \\
& Restricted F-test $=11.21(\mathrm{p}=0.0011<0.05)$ & &
\end{tabular}

Hauman Test $=1.72(\mathrm{P}=0.1892<0.05)$

Source: Author's computation, (2019).

\section{Conclusion}

This study discovered Southwest States performances in resources mobilization and showed a significant trend as each of the six states showcased a fluctuating pattern of resources mobilization although in varying strength, which could be traceable to some subjective factors such as age of the state, availability of infrastructural facilities, industries and diverse taxable economic activities, as well as nearness to points of exit and/or entry into the country. Also the study established that internal resources mobilization has significant positive influence on the level of financial control of government budget in Southwest Nigeria. In other words the study identified the importance of internally generated revenue in the discussion of budget implementation and control in southwest Nigeria. Thus Southwest State Governments should ensure adequate generation of revenue within the States, so as to boost the level of financial control in government budget process.

\section{Conflicts of Interest}

The authors declare no conflicts of interest regarding the publication of this paper.

\section{References}

[1] Omopariola, O. (1991) The Defects of Nigerian Government Budgets as a Frame- 
work for Performance Evaluation in the Nigerian Public Service. Ife Journal of Economics and Finance, 1, 41-52.

[2] Omopariola, O. (2001) Nigeria's Financial Management Nightmare. An Inaugural Lecture Series 153 of the Obafemi Awolowo University Ile-Ife. 1-51.

[3] Omolehinwa, E. (2001) Government Budgeting In Nigeria. Purmark Nigeria Ltd., Lagos.

[4] Obadan, M.I. (2003) National Development Planning and Budgeting in Nigeria: Some Pertinent Issues. Broadway Press Limited, Lagos.

[5] Olaoye, F.O. (2008) Concepts and Practice of Public Sector Accounting in Nigeria. Aseda Publishing, Ibadan.

[6] Mbanefor, G.F. (1999) Towards Effective Budgeting under a Democratic System. CBN Bullion, 23.

[7] Nwagbara, U. (2012) Beyond the Allure of Budgeting: Assessing the Suitability of Budget for Organisational Performance in the 21st Century. Polish Journal of Management Studies, 5, 78-88.

[8] Rivenbark, W.C. and Peterson, E.J. (2008) A Balanced Approach to Implementing Balanced Scorecard. Popular Government Journal, 74, 31-37.

[9] Carreras, A., Mujtaba, B.G. and Cavica, F.J. (2011) Don't Blame the Budget Process: An Exploration of Efficiency, Effectiveness and Ethics. Business and Management Review, 1, 5-13.

[10] Robinson, M. (2002) Financial Control in Australian Government Budgeting. Public Budgeting and Finance, 22, 80-93. https://doi.org/10.1111/1540-5850.00067

[11] Aristovnik, A. and Seljak, J. (2009) Performance Budgeting: Selected International Expansion and Some Lessons for Slovenia. MPRA Paper 15499, University Library of Munich, Munich.

[12] Jensen, C.M. (2011) Corporate Budgeting Is Broken-Let's Fix It. Harvard Business Review, 79, 95-101.

[13] Hope, J. and Fraser, R. (2003) Who Needs Budget. Harvard Business Review, 81, 108-115.

[14] Daum, J.H. (2002) Beyond Budgeting: A Model for Performance Management and Controlling in the 21st Century. Controlling \& Finance, 5, 33-34.

[15] Jensen, C.M. (2003) Paying People to Lie: The Truth about the Budgeting Process. European Financial Management, 9, 379-406. https://doi.org/10.1111/1468-036X.00226

[16] Pollit, C. and Bouchert, C. (2004) Public Management Reform: A Comparative Analysis. 2nd Edition, Oxford University Press, Oxford.

[17] Howard, M. and Kilmartin, B. (2006) Assessment of Benchmarking within Government Organisation. Accenture's Innovation Unbound Series. http://www.aceanture:assessmentofbenchmarking.com

[18] Asaju, K., Adagba, S.O. and Kajang, T.J. (2014) The Efficacy of Fiscal Policy in Promoting Economic Growth and Reducing Poverty in Nigeria. Research in World Economy, 5, 56-76. https://doi.org/10.5430/rwe.v5n1p65

[19] Onore, J.O. (2014) Budget Implementation in Delta State-Nigeria, 1999-2010. International Journal of Academic Research in Business and Social Sciences, 4, 235-442. https://doi.org/10.6007/IJARBSS/v4-i3/712

[20] Ugoh, C. and Ukpere, W. (2009) Problems and Prospects of Budgeting and Budget Implementation in Local Government system in Nigeria. African Journal of Busi- 
ness Management, 3, 836-846.

[21] Bleaney, M. (2010) Budget Institutions and Fiscal Performance in Africa. CREDIT Research Paper, No. 10/02.

[22] Ojo, E.O. (2012) Constraints on Budgeting and Development Plan Implementation. Journal of Sustainable Development in Africa, 1, 445-456.

[23] Oshisami, K. (1992) Government Accounting and Financial Control. Spectrum Books Ltd., Ibadan.

[24] Pandey, I.M. (2004) Essentials of Management Accounting. Vikas Publishing House PVT Ltd., New Delhi.

[25] Osiyemi, I.M. (2005) Budgeting and Financial Reporting for Efficient Economic Management in the Public Sector. The Nigerian Accountant, 38, 42-43.

[26] Wehner, J. (2003) Parliament and the Budget: A Short Introduction from a Civil Society Perspective. International Budget Project, Washington DC. http://www.InternationalBudget.org

[27] Premchard, A. (1983) Government Budgeting and Expenditure Control: Theory and Practices. IMF, Washington DC.

[28] Olowolaju, P.S., Ajibola, O., Ishola, R.A. and Falayi, I. (2014) Federal Government Statutory Fund Allocation to States in Nigeria, West Africa: Any Reasonable Story to Tell? American International Journal of Social Science, 3, 152-164. 